Research article

\title{
New species of Troglomyces and Diplopodomyces (Laboulbeniales, Ascomycota) from millipedes (Diplopoda)
}

\author{
Sergi SANTAMARÍA ${ }^{1, *}$, Henrik ENGHOFF ${ }^{2}$ \& Ana Sofía P.S. REBOLEIRA ${ }^{3}$ \\ ${ }^{1}$ Unitat de Botànica, Departament de Biologia Animal, de Biologia Vegetal i d'Ecologia, \\ Facultat de Biociències, Universitat Autònoma de Barcelona, \\ 08193-Cerdanyola del Vallès (Barcelona), Spain. \\ ${ }^{2,3}$ Natural History Museum of Denmark (Zoological Museum), University of Copenhagen, \\ Universitetsparken 15, DK-2100 København Ø, Denmark. \\ *Corresponding author: sergi.santamaria@uab.es \\ ${ }^{2}$ Email: henghoff@snm.ku.dk \\ 33Email: sreboleira@snm.ku.dk
}

\begin{abstract}
We describe five new species of fungi of the order Laboulbeniales Lindau growing on millipedes and belonging to the genera Diplopodomyces W.Rossi \& Balazuc and Troglomyces S.Colla. Three new species of Diplopodomyces, viz. Diplopodomyces coronatus Santam., Enghoff \& Reboleira sp. nov. living on Serboiulus spelaeophilus Gulicka, 1967 from Bulgarian caves, Diplopodomyces liguliphorus Santam., Enghoff \& Reboleira sp. nov. on an unidentified species of Spirobolida from Sri Lanka, and Diplopodomyces ramosus Santam., Enghoff \& Reboleira sp. nov. on Pachyiulus spp. from Turkey, Macedonia and Serbia; and two new species of Troglomyces, viz. Troglomyces dioicus Santam., Enghoff \& Reboleira sp. nov. on Nepalmatoiulus sp. from Myanmar, and Troglomyces tetralabiatus Santam., Enghoff \& Reboleira sp. nov. on Caucaseuma Strasser, 1970 and Heterocaucaseuma Antić \& Makarov, 2016 from caves in Western Caucasus. Troglomyces dioicus sp. nov. is the first dioecious species described in the genus Troglomyces. Keys for all hitherto known species of Diplopodomyces and Troglomyces are presented, as is a discussion of the status of both genera. Additional records for Diplopodomyces lusitanipodos Santam., Enghoff \& Reboleira and Troglomyces manfrediae S.Colla are also included.
\end{abstract}

Keywords. Diplopodomyces, identification keys, Laboulbeniales, Millipedes, Troglomyces.

Santamaría S., Enghoff H. \& Reboleira A.S.P.S. 2018. New species of Troglomyces and Diplopodomyces (Laboulbeniales, Ascomycota) from millipedes (Diplopoda). European Journal of Taxonomy 429: 1-20. https://doi.org/10.5852/ejt.2018.429

\section{Introduction}

Fungi of the order Laboulbeniales Lindau represent more than 2000 species placed in the Phylum Ascomycota (Weir \& Hammond 1997; Santamaría et al. 2017). They are well characterized by having very minute compact thalli, mostly $50-500 \mu \mathrm{m}$ in length. Laboulbeniales are obligate biotrophs that live attached to the tegument of arthropods, mainly insects, but also arachnids and millipedes (Santamaría 
et al. 2017). It is a common view that these fungi have little or no effect on their hosts (Benjamin 1971; Tavares 1985). Fitness effects have been estimated by a few controlled studies (Whisler 1968; Strandberg \& Tucker 1974), as well as some insights into how these fungi may influence the behaviour of their hosts (Konrad et al. 2014; Báthori et al. 2017; Csata et al. 2017). Their source of nutrients is debatable, but they are believed to draw them from their hosts through absorption or via contact with living tissues (Scheloske 1969; Benjamin 1971; Tavares 1985). Traditionally, Laboulbeniales have been considered ectoparasites, because some of them show a more or less conspicuous haustorium that penetrates into the host body (Thaxter 1896). However, recent studies (Tragust et al. 2016) demonstrate that a few species do not show these structures and therefore, at least in these cases, Laboulbeniales should be defined as commensalistic. This point of view is not new, having been thoroughly used by some previous authors (Tamada \& Kaya 1993; Lawrence \& Milner 1996; Jolivet 1998). It seems almost unquestionable that both life styles, parasitism and commensalism, exist in Laboulbeniales, and the use of the term "ectobionts" for Laboulbeniales, instead of the most restrictive "ectoparasites", is suggested.

Laboulbeniales were assumed to be very uncommon on millipedes (Diplopoda) but recent collaboration of myriapodologists with laboulbeniologists has revealed that this is not beyond doubt. The number of these fungi living on millipedes has been substantially increased during recent years from eight species (Santamaría et al. 2014), to 24 (Enghoff \& Santamaría 2015; Santamaría et al. 2016), and 29 if the new taxa described here are included. In the present paper five new species of the genera Troglomyces S.Colla and Diplopodomyces W.Rossi \& Balazuc are described, and new information about these genera which are found only on millipedes is also given.

\section{Material and methods}

Millipede hosts are preserved in 70\% ethanol and were obtained from the zoological collections of the Natural History Museum of Denmark (ZMUC), except for specimens of Pachyiulus cattarensis Latzel, 1884 which are from the Naturhistorisches Museum of Vienna (NHMW). Fungi were detected by the observation of millipedes under 40-80× magnification of a dissecting microscope. Permanent slides were prepared following previously described methods (Rossi \& Santamaría 2015), and are kept in the BCB Mycotheca of the Universitat Autònoma de Barcelona (BCB slides), and in the Mycological Collection Herbarium of the Natural History Museum of Denmark, University of Copenhagen (C-F slides). Photomicrographs were made with a Jenoptik ProgRes 10 Plus digital camera on a Leica DMR microscope equipped with differential interference contrast optics (DIC). Images were processed with Photoshop CS5 software.

We mostly follow the terminology according to Tavares (1985).

\section{List of abbreviations used in the descriptions and captions of figures}

$\begin{array}{lll}\mathrm{I} & = & \text { basal cell of receptacle } \\ \mathrm{II} & = & \text { suprabasal cell of receptacle } \\ \mathrm{III} & = & \text { terminal cell of receptacle } \\ \mathrm{VI} & = & \text { perithecial stalk cell } \\ \mathrm{VII} & = & \text { secondary stalk cell of perithecium } \\ \mathrm{a} & = & \text { primary septum } \\ \text { an } & = & \text { antheridium } \\ \mathrm{a} & = & \text { ascospores } \\ \mathrm{li} & = & \text { ligulated protuberance of perithecium } \\ \mathrm{m} & = & \text { one of the three perithecial basal cells } \\ \mathrm{n} & = & \text { one of the three perithecial basal cells } \\ \mathrm{n} & = & \text { one of the three perithecial basal cells }\end{array}$




$\begin{array}{lll}\mathrm{sc}-\mathrm{an} & = & \text { antheridial supporting cell, also called corner cell } \\ \mathrm{sp} & = & \text { spermatium } \\ \mathrm{sx} & = & \text { spore apex, spinous process or remains of the original spore apex } \\ \mathrm{tr} & = & \text { trichogyne } \\ \mathrm{w}_{\mathrm{n}} & = & \text { perithecial outer wall cell indicating the tier }(\mathrm{n})\end{array}$

\title{
Institutional abbreviations
}

$\mathrm{BCB}=$ Herbarium of the Autonomous University of Barcelona

$\mathrm{C}-\mathrm{F}=$ Herbarium of the Natural History Museum of Denmark, University of Copenhagen

NHMW $=\quad$ Naturhistorisches Museum, Wien

ZMUC $=\quad$ Natural History Museum of Denmark (Zoological Museum), University of Copenhagen

\section{Results}

\author{
Order Laboulbeniales Lindau \\ Suborder Laboulbeniineae Thaxter \\ Family Laboulbeniaceae Peyritsch \\ Subfamily Laboulbenioideae s. str. \\ Tribe Laboulbenieae Thaxter \\ Subtribe Stigmatomycetinae (Thaxter) I.I.Tavares \\ Genus Diplopodomyces W.Rossi \& Balazuc
}

Revue de Mycologie (Paris) 41: 528 (Rossi \& Balazuc 1977). - Type species: D. callipodos W.Rossi \& Balazuc ex W.Rossi

\section{Brief description}

Receptacle three-celled, with superposed cells I and II. Cell III lateral to cell II. Septum II-III vertical to oblique. Perithecium with four or five strongly unequal outer wall cells in each vertical row. The original description was extended by Santamaría et al. (2014). Six species.

\section{Identification key to the Diplopodomyces species}

1. Perithecium bearing one ligula-like protuberance.

D. liguliphorus Santam., Enghoff \& Reboleira sp. nov.

- Perithecium without protuberances

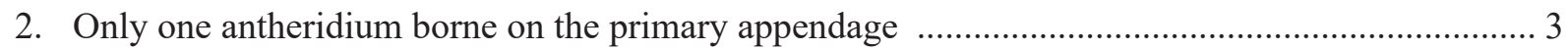

- Two or more functional antheridia on the primary appendage …................................................... 4

3. Appendage bearing a single antheridium on the second cell; antheridium without supporting cell; on Lusitanipus Mauriès, 1978 and Cyphocallipus Verhoeff, 1909 (Callipodida) and Guadarramosoma Gilgado, Ledesma, Enghoff \& Mauriès, 2017 (Chordeumatida) .................................................. D. lusitanipodos Santam., Enghoff \& Reboleira

- Appendage bearing a single antheridium on the first cell. Antheridium with supporting cell. On Serboiulus (Julida)

D. coronatus Santam., Enghoff \& Reboleira sp. nov.

4. Appendage consisting of five superposed cells. Two antheridia on the second cell. These antheridia and the distal part of the appendage oriented as the axes of a regular tetrahedron. On Callipus (Callipodida) D. callipodos W.Rossi \& Balazuc ex W.Rossi

- Appendage consisting of more than seven cells. Usually more than two functional antheridia; when only two, not positioned together on the second cell of the appendage 
5. Dimorphic. Primary appendage strongly bent laterally, unbranched or with few inconspicuous branches on the distal part. On Lusitanipus (Callipodida) D. veneris Santam., Enghoff \& Reboleira

- Not dimorphic. Primary appendage profusely ramified above the fourth cell. On Pachyiulus Berlese, 1883 (Julida) D. ramosus Santam., Enghoff \& Reboleira sp. nov.

\section{Diplopodomyces coronatus Santam., Enghoff \& Reboleira sp. nov. MycoBank No: MB824136}

Fig. 1

\section{Diagnosis}

Similar to Diplopodomyces lusitanipodos Santam., Enghoff \& Reboleira, but differing for the single antheridium on the lower cell of the appendage and the conspicuous four blunt lips on the perithecial apex.

\section{Etymology}

The species epithet means "crown-like", in relation to the crown-like perithecial tip, resulting from the peculiar disposition of its four apical wall cells.

\section{Material examined}

\section{Holotype}

BULGARIA: Western Stara Planina, Mt. Bell mel. Distr. Montana, Cave Parasinskata, guano clay, on Serboiulus spelaeophilus Gulicka, 1967 (Julida), 25 Feb. 2000, B. Petrov \& P. Tzankov leg., slide C-F92266.

\section{Isotypes}

BULGARIA: Same data as holotype. Slides SS E585a, SS E585c, SS E585d and SS E585e (BCBMycotheca).

\section{Description}

Thallus hyaline, except for the blackened foot.

Basal cell (I) slightly longer than broad, enlarged distally, with the base abruptly constricted at the point of junction with the blackened foot (it breaks easily with manipulation). Suprabasal cell (II) trapezoidal, slightly longer than broad. Cell III nearly twice as long as broad. Septum I-II horizontal, septa II-III and II-VI oblique. Septum II-VI two times longer than septum II-III. Primary septum (a) slightly constricted, oblique.

Primary appendage strongly divergent from the perithecial axis, forming an angle of $45-70^{\circ}$, unbranched, consisting of up to 4-5 similarly elongated cells, gradually tapering distally towards a blunt apical cell, if unbroken. Spiny remains of spore apex (sx) conspicuous, stout and blunt, located on the distal margin of the 4th cell. A single bottle-shaped, narrow and elongate antheridium, borne on a corner cell at the adaxial side of appendage basal cell.

Perithecial stalk cell (VI) flattened, trapezoidal, 2.5 times as broad as long. Secondary stalk cell (VII) and basal cells of perithecium (n, m, n') well defined. Perithecium almost conical, broadest near the base, gradually tapering into a truncate apex. The latter bears four rather conspicuous and blunt lips, formed by upper tier of perithecial wall cells $\left(\mathrm{w}_{4}\right)$. Margins of perithecium showing a slight indentation at the junction between what seem the $\mathrm{w}_{3}$ and $\mathrm{w}_{4}$ tiers, above which the margin is slightly convex (Figs 1C-E). 


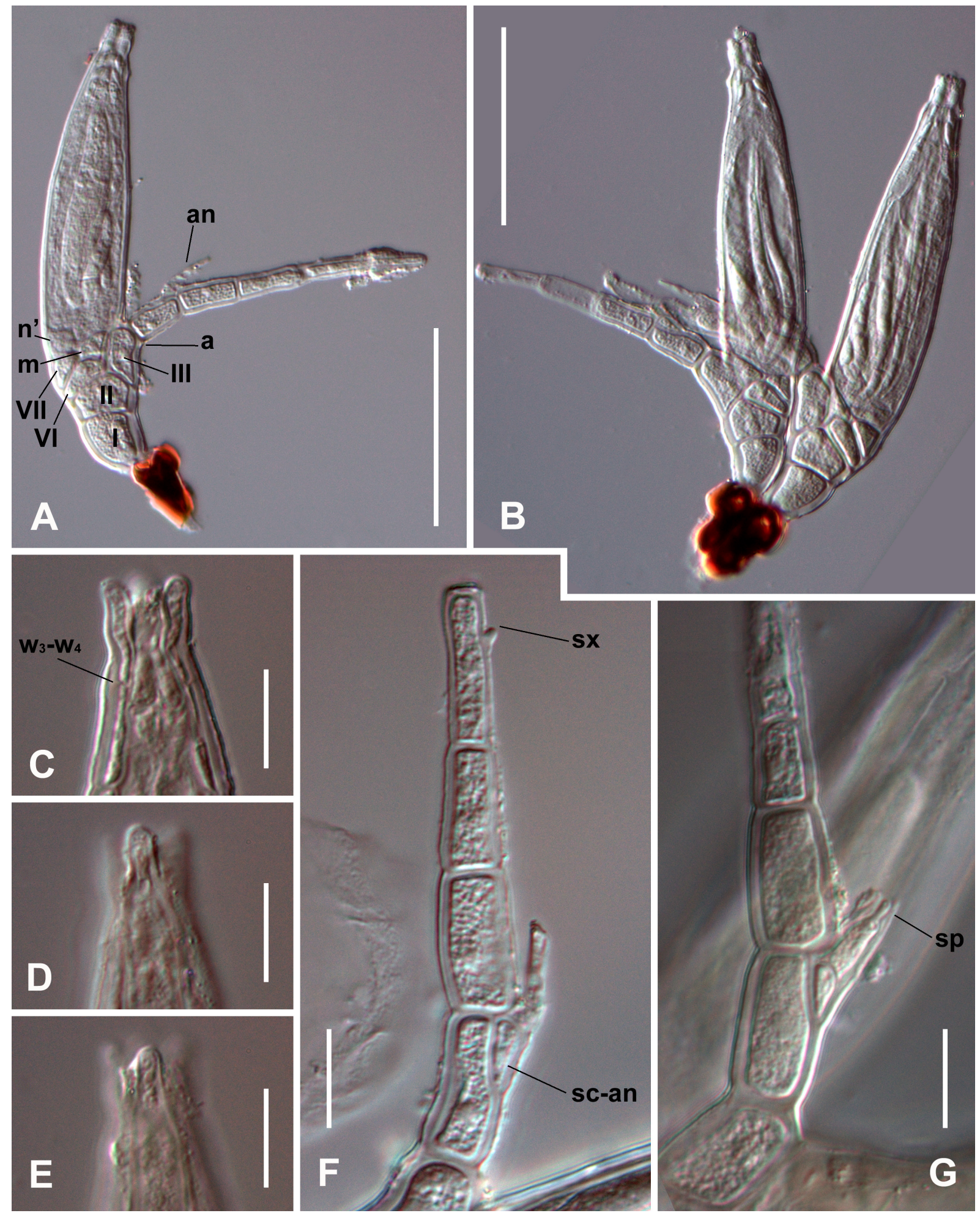

Fig. 1. Diplopodomyces coronatus Santam., Enghoff \& Reboleira sp. nov. A. Mature thallus with labelling of cells and other elements. B. Paired mature thalli. C-E. Perithecial apex at three different focusing levels to highlight the four blunt lips and the bulging at $\mathrm{w}_{3}-\mathrm{w}_{4}$ septum. F- G. Details of primary appendage. Scale bars: $50 \mu \mathrm{m}(\mathrm{A}-\mathrm{B})$ and $10 \mu \mathrm{m}(\mathrm{C}-\mathrm{G})$. Photographs from: slides SS E585a (A-E) and C-F-92266 (F-G). 
Length from foot to apex of perithecium 104-139 $\mu \mathrm{m}$. Perithecium (including basal cells) 70-89 $\times$ $18-23 \mu \mathrm{m}$. Primary appendage (from primary septum to apex, undamaged) $48-84 \mu \mathrm{m}$.

\section{Remarks}

Thalli are sparsely distributed on the host body, mostly on the legs, a few on the body but the latter in poor condition.

Exceptionally one immature thallus bears an additional antheridium on the second cell of appendage, identical in shape, size, position and orientation to the usually single antheridium.

As mentioned in the diagnosis, this species seems to be closely related to Diplopodomyces lusitanipodos, but differs from the latter for the position of the single antheridium on the appendage basal cell, instead than on the second appendage cell. Moreover, in Diplopodomyces coronatus Santam., Enghoff \& Reboleira sp. nov. the antheridium is born on a corner cell (sc-an, Fig. 1F), which is absent in Diplopodomyces lusitanipodos. The perithecial apex appears to be ornate with four protuberant lips, i.e., the upper outer wall cells ( $\mathrm{w}_{4}$, Fig. 1C-E), whereas it is blunt although showing four minute preapical rounded protuberances in Diplopodomyces lusitanipodos (Santamaría et al. 2014: 1031). The sx (Fig. 1F) is hardly distinguishable, short, blunt and stout on the fourth appendage cell, whereas it is spiny, easily recognizable, and usually on the third appendage cell in Diplopodomyces lusitanipodos.

The host is a purely cavernicolous species (Kime \& Enghoff 2017).

Diplopodomyces liguliphorus Santam., Enghoff \& Reboleira sp. nov. MycoBank No: MB824137

Fig. 2

\section{Diagnosis}

The presence of a ligula-like protuberance on the perithecial apex is the most striking characteristic of this species which does not seem to be closely related to any other species in this genus.

\section{Etymology}

The species epithet means "bearing a tongue", in relation to the perithecial protuberance.

\section{Material examined}

\section{Holotype}

SRI LANKA: s.d., on Spirobolida indet. (family uncertain), slide C-F-92267.

\section{Isotypes}

SRI LANKA: Same data as holotype. Slides SS E575a and SS E575c (BCB-Mycotheca).

\section{Description}

Cells II, III, VI and basal cell of primary appendage bright reddish coloured; the rest of the thallus is hyaline, except for the blackened foot.

Basal cell (I) two times as long as broad, typically obconical, narrow at the base and gradually broadening distally. Suprabasal cell (II) more or less trapezoidal and isodiametric. Cell III smaller than II, slightly longer than broad, laterally adnate and exceeding in length cell VI. Septum I-II horizontal. Septum II-III oblique, almost half in length than I-II. Septum II-VI very oblique, as long as septum I-II. 
Primary appendage unbranched, variably bent, consisting of up to 8 cells, gradually tapering distally. Basal cell of primary appendage three times as long as broad, distinctly larger and darker than other cells of appendage. Typically a single flask-shaped antheridium without supporting cell is borne on the second cell of appendage. Spiny remains of spore apex (sx) conspicuous, stout, on the third cell, rarely on the fourth cell of appendage.

Perithecial stalk cell (VI) triangular to rhomboid, obliquely arranged above cell II and under the perithecial body. Secondary stalk cell (VII) and basal cells of perithecium (n, n', m) hardly distinguishable. Perithecium fusiform, with a blunt apex which bears a small but evident, erect, rounded, ligulate protuberance (li), formed by a $\mathrm{w}_{4}$ perithecial wall cell.

Length from foot to apex of perithecium 119-192 $\mu \mathrm{m}$. Perithecium (including basal cells) $68-121 \times$ 21-31 $\mu \mathrm{m}$. Primary appendage (from primary septum to apex, undamaged) $76-123 \mu \mathrm{m}$.

\section{Remarks}

Abundant thalli of the new species were scattered on legs and body rings (most on ventral side) of the frontal part of the millipede.
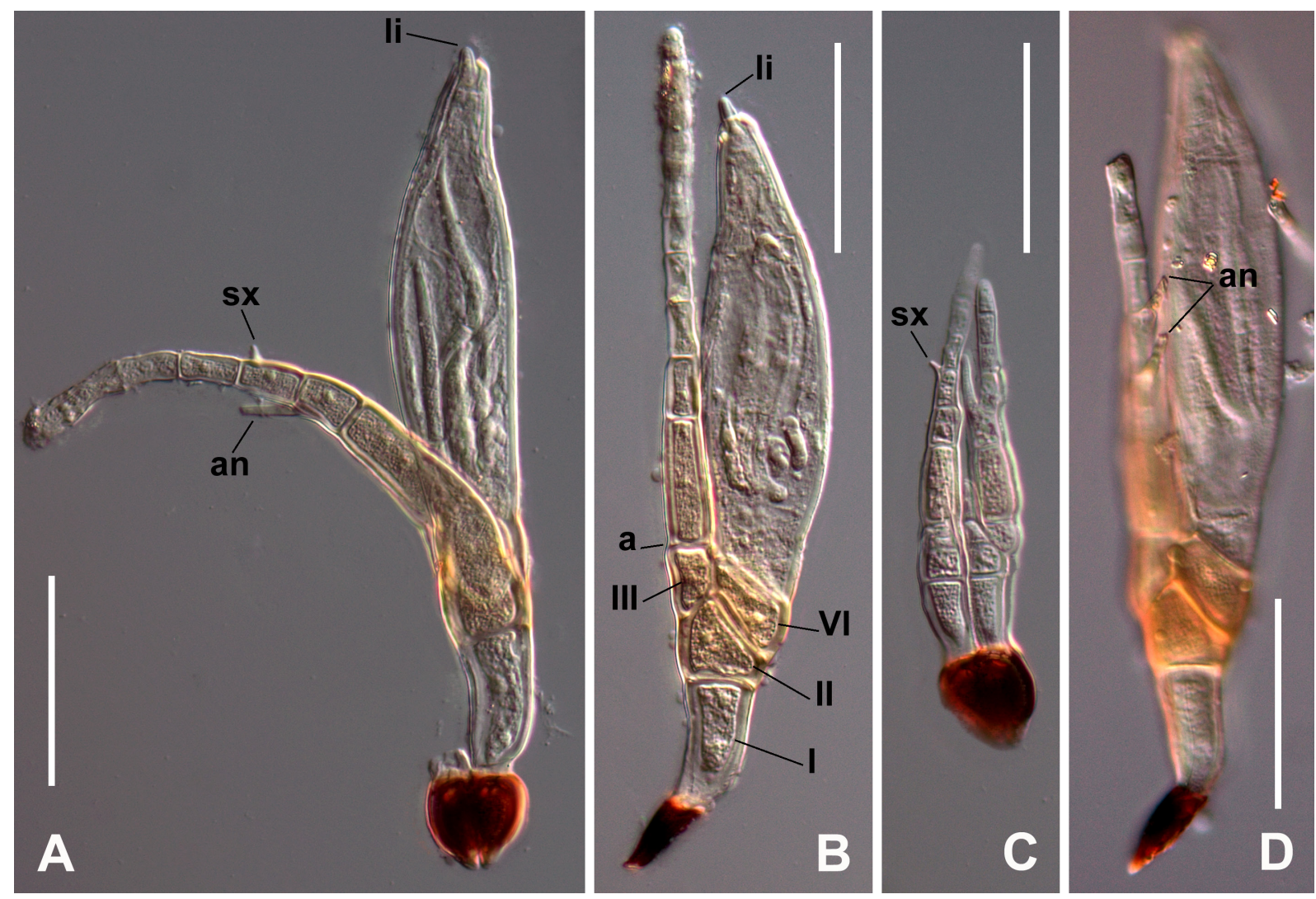

Fig. 2. Diplopodomyces liguliphorus Santam., Enghoff \& Reboleira sp. nov. A-B. Mature thalli with labelling of cells and other elements. C. Pair of young thalli focused to show the original spinous spore apex (sx). D. Mature thallus focused to show the antheridium (an). Scale bars: $50 \mu \mathrm{m}$. Photographs from: slides C-F-92267 (A-B), SS E575c (C) and SS E575a (D). 
Rarely a second, additional antheridium was seen on the third appendage cell (an, Fig. 2D). Interestingly, the nuclei appear to be conspicuous in all cells of the appendage and also inside the basal cell (I) of the receptacle when seen with DIC optics.

This species is well distinguished by the protuberant lip on the perithecium, the reddish colour in some receptacle cells, and poorly defined walls of the basal cells of the perithecium, a characteristic unknown in the tribe Laboulbenieae but found in other genera of other tribes.

Diplopodomyces ramosus Santam., Enghoff \& Reboleira sp. nov. MycoBank No: MB824138

Fig. 3

\section{Diagnosis}

Characterized by a very long and ramified primary appendage, by the scattered antheridia along the main axis of the appendage and by the stocky perithecium bearing four conspicuous acute lips on the apex.

\section{Etymology}

The species epithet means "branched", in relation to the large and ramified primary appendage.

\section{Material examined}

\section{Holotype}

TURKEY: Mugla province, Toparlar, on Pachyiulus sp. (Julida), under litter and logs in a wet Liquidambar orientalis forest, 13 Nov. 2013, H. Sundberg leg., slide C-F-92268.

\section{Paratypes}

REPUBLIC OF MACEDONIA: Nerez - Gornja Voda near Üsküb (Skopje), NHMW no. 8725, 6 Jun. 1906 [ex. Mus. Wien, Inv. No. NHMW 8724], on Pachyiulus cattarensis, Slide SS E619 (BCBMycotheca); ibidem, 21 May 1906, slides SS E620a and SS E620b (BCB-Mycotheca). Millipede host specimen in NHMW.

KOSOVO (SERBIA): Kacanik, oak forest, 22 May 1906, Attems leg. [ex Mus. Wien, Inv. no. NHMW 8727], on one male and two females of Pachyiulus cattarensis, slides SS E623a and SS E623b (BCBMycotheca). Millipede host specimens in NHMW.

\section{Description}

Thallus yellowish-brown, often darker on cells II, III, VI, VII and perithecial basal cells, forming a defined stalk below the perithecium. Blackened foot, rather elongate and pointed.

Basal cell (I) 3-4 times as long as broad, with slightly divergent margins towards the apex and nearly parallel margins in the central area; straight except for the constricted, curved and geniculate base above the foot. Suprabasal cell (II) trapezoidal, almost isodiametric or slightly broader than long. Septum I-II horizontal. Cell III 1.5 times as long as broad, cylindrical (rectangular in optical section), adnate to cell VI and to the base of the perithecium. Septum II-III slightly oblique. Septum II-VI strongly oblique.

Primary appendage very long, consisting of a main axis of 6-9 cells which are 3-4 times longer than broad, each bearing 1-3 flask-shaped antheridia on distal and relatively large corner cells. The appendage ramifies approximately above the 4th cell, where corner cells grow into thin, long, and flexuous branches, which often ramify again forming a confused mass of appendages glued together with dirt. Primary 
SANTAMARÍA S. et al., New species of Laboulbeniales from millipedes
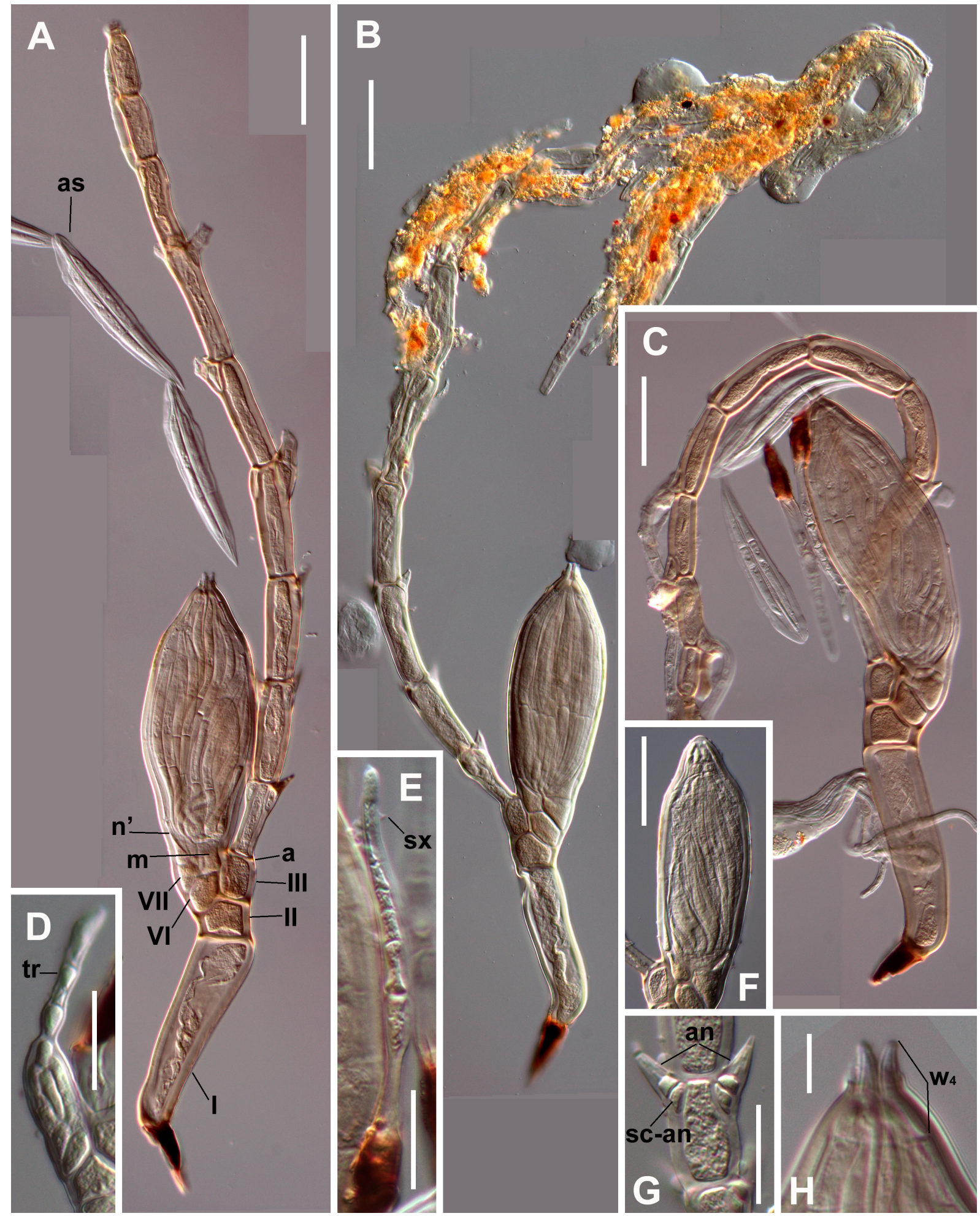

Fig. 3. Diplopodomyces ramosus Santam., Enghoff \& Reboleira sp. nov. A-C. Mature thalli with labelling of cells and other elements. D. Immature perithecium showing the trichogyne (tr). E. Young thallus showing the spinous remains of the original spore apex (sx). F. Slightly immature perithecium. G. Detail of antheridia. H. Detail of well mature perithecium apex showing acute ligulae. Scale bars: $50 \mu \mathrm{m}(\mathrm{A}-\mathrm{C}, \mathrm{F}), 25 \mu \mathrm{m}(\mathrm{D}-\mathrm{E}, \mathrm{G})$, and $10 \mu \mathrm{m}(\mathrm{H})$. Photographs from: slides SS E583a (A, C, E, H), C-F-92268 (B), SS E620a (D, G) and SS E623b (F). 
septum (a) well defined by a constriction and contrasting colour between the darker cell III and the pale basal cell of primary appendage, below the base of the perithecium.

Perithecial stalk cell (VI) rhomboidal, arranged obliquely between cells II and VII; slightly smaller than cell II. Secondary stalk cell (VII) and basal cells of perithecium (n, m, n') well defined, forming a more or less defined stalk or pedicel under the ascogenic mass of the perithecium. Perithecium broadly elliptical, with a constricted lower third, an inflated venter, and a narrow tip; the apex bears 4 small, acute, teeth-like ligulae, resembling teeth, formed by the $\mathrm{w}_{4}$ tier of perithecial wall cells.

Length from foot to apex of perithecium 248-336 $\mu \mathrm{m}$. Perithecium (including basal cells) 130-182 × 51$67 \mu \mathrm{m}$. Ascospores $105-111 \mu \mathrm{m}$ long. Primary appendage (from primary septum to apex, undamaged) $432-860 \mu \mathrm{m}$ long.

\section{Remarks}

This species grows on male hosts around the gonopods and on females close to the gonopores at the base of leg-pairs 1 and 2. In this feature it is analogous with Diplopodomyces veneris Santam., Enghoff \& Reboleira (Santamaría et al. 2014) but despite this coincidence, the morphological characteristics of both species are incomparable. Moreover, Diplopodomyces ramosus Santam., Enghoff \& Reboleira sp. nov. does not show dimorphism in relation to the host sex.

The spiny remains of the spore apex (sx) is not visible on mature thalli. Only one very young thallus has been observed showing this characteristic (sx, Fig. 3E). The four small ligulae of the perithecial apex are well distinguished only in over-mature thalli, not when ascospores start being visible inside the perithecium (Fig. 3F) (which is the usual condition for most Laboulbeniales when we referring to a mature perithecium).

The four ligulae protrude when most of the external wall of the perithecium is broken and the ascospores have been released.

Both host species belong to the problematic genus Pachyiulus Berlese, 1883 (Frederiksen et al. 2012). Pachyiulus cattarensis occurs in forests as well as open areas from sea level up to $2400 \mathrm{~m}$ (Kime \& Enghoff 2017).

\section{Genus Troglomyces S.Colla}

Nuovo Giornale Botanico Italiano 39: 450 (Colla 1932). - Type species: T. manfrediae S.Colla

\section{Brief description}

Receptacle three-celled, with superposed cells I, II and III. Cells II and III narrow and adnate to the perithecium. Perithecium with five, rarely six, outer wall cells in each vertical row. Perithecial apex bearing four conspicuous lobes. The original description was emended by Enghoff \& Santamaría (2015). Eight species.

\section{Identification key to the Troglomyces species}

1. Dioecious; male thalli consisting of 6 superposed cells, the uppermost being the antheridium; on Nepalmatoiulus Mauriès, 1983 (Julida) T. dioicus Santam., Enghoff \& Reboleira sp. nov.

- Monoecious; antheridia on primary appendage of female thalli

2. Lower cell of primary appendage bearing one to several antheridia ............................................. 3

- Lower cell of primary appendage without antheridia, which are always located on cells above...... 5

3. Only one antheridium 
- Antheridia 4 to 6 arranged in one or two groups; on Leptoiulus Verhoeff, 1894 (Julida) .................................................................... T. botryandrus Santam., Enghoff \& Reboleira

4. Appendage bifurcate above the second cell by means of an oblique septum; on Ophyiulus Berlese, 1884 (Julida)

T. rossii Santam., Enghoff \& Reboleira

- Appendage unbranched (if branched not as above); on other genera of Julida

T. manfrediae S.Colla

5 Three antheridia on the third, fourth and fifth cell of appendage; on Archiboreoiulus Brolemann, 1921 (Julida) T. triandrus Santam. \& Enghoff

- Second cell of appendage functioning as or bearing an antheridium 6

6. Perithecial tip with two or four apical cells protruding like ligulae ............................................ 7

- Perithecial tip without protruding cells; on Iberoiulus Mauriès, 1985 (Julida)

T. pusillus Santam. \& Enghoff

7. Perithecial tip with two protruding apical cells; on Acipes (Blaniulidae)

T. bilabiatus Santam. \& Enghoff

- Perithecial tip with four protruding apical cells; on Caucaseuma Strasser, 1970 and Heterocaucaseuma Antić \& Makarov, 2016 (Chordeumatida) ....T. tetralabiatus Santam., Enghoff \& Reboleira sp. nov.

Troglomyces dioicus Santam., Enghoff \& Reboleira sp. nov.

MycoBank No: MB824139

Fig. 4

\section{Diagnosis}

First dioecious species in the genus, with female thalli characterized by a very short cell III and a septum II-III placed under the level of the perithecial base, whereas in the other species cell III is taller and the septum II-III is clearly higher up.

\section{Etymology}

Self-defined by its species epithet, meaning "two households".

\section{Material examined}

\section{Holotype}

MYANMAR: Mandalay Division, 7 km NW Mogok, above road Mogok-Bemardmyo, S. Panlin village, west slope of Mt. Taung Mae, $22^{\circ} 58^{\prime} 09^{\prime \prime} \mathrm{N} 96^{\circ} 27^{\prime} 13^{\prime \prime}$ E, 1710-1750 m a.s.1., on Nepalmatoiulus sp. (Julida), 10-18 Jun. 2014, Brunke \& Schillhammer leg., slide C-F-92269.

\section{Isotypes}

MYANMAR: Same data as holotype. Slides SS E617a, SS E617c, SS E617d and SS E617e (BCBMycotheca).

\section{Description}

Dioecious. Both male and female thalli are hyaline except for the darkened feet.

Male thalli. Consisting of six superposed cells. Basal cell (I) about 3 times as long as broad. Suprabasal cell (II) small and squared. Cell III 1.5 times as long as broad. Primary septum well distinguished. Fourth cell 1.5 times as long as broad. Fifth cell squared, very small, bearing the single, apical, bottleshaped antheridium. No spiny remains of spore apex because it is coincident with the apex of efferent tube, i.e., where the discharging pore is found. 
Female thalli. Basal cell (I) twice or more as long as broad, enlarged distally, slightly constricted at the base. Suprabasal cell (II) as long as broad, laterally adnate to cell VI, broadened at base where in contact with cell I, narrowed toward distal end. Cell III very narrow, 3 times as long as broad, laterally adnate to perithecium. Septum I-II horizontal. Septum II-III horizontal or slightly oblique, below the level of septum VI-VII.

Primary appendage unbranched, forming an angle of almost $90^{\circ}$ with main axis of thallus, consisting of up to 4 cells, of which the lower is about 4 times as long as broad, the others gradually shorter and tapering distally. Spiny remains of spore apex (sx) difficult to see in mature thalli (Fig. 4A), but well visible in very young thalli (Fig. 4D).

Perithecial stalk cell (VI) triangular, as long as broad, resting in the concave apico-ventral side of cell II. Secondary stalk cell (VII) wedge-shaped, resting on the outer (ventral) corner of cell VI. Perithecium fusiform, stout, with broad venter, maximum width near lower $1 / 4-1 / 5^{\text {th }}$, gradually tapering upwards, more abruptly upwards from $\mathrm{w}_{2}-\mathrm{w}_{3}$ septa. The tip is asymmetric, slightly bent dorsally, forming first a neat constriction, followed by a bulge and ending with four small lips. Dorsal side rather straight, ventral side convex.
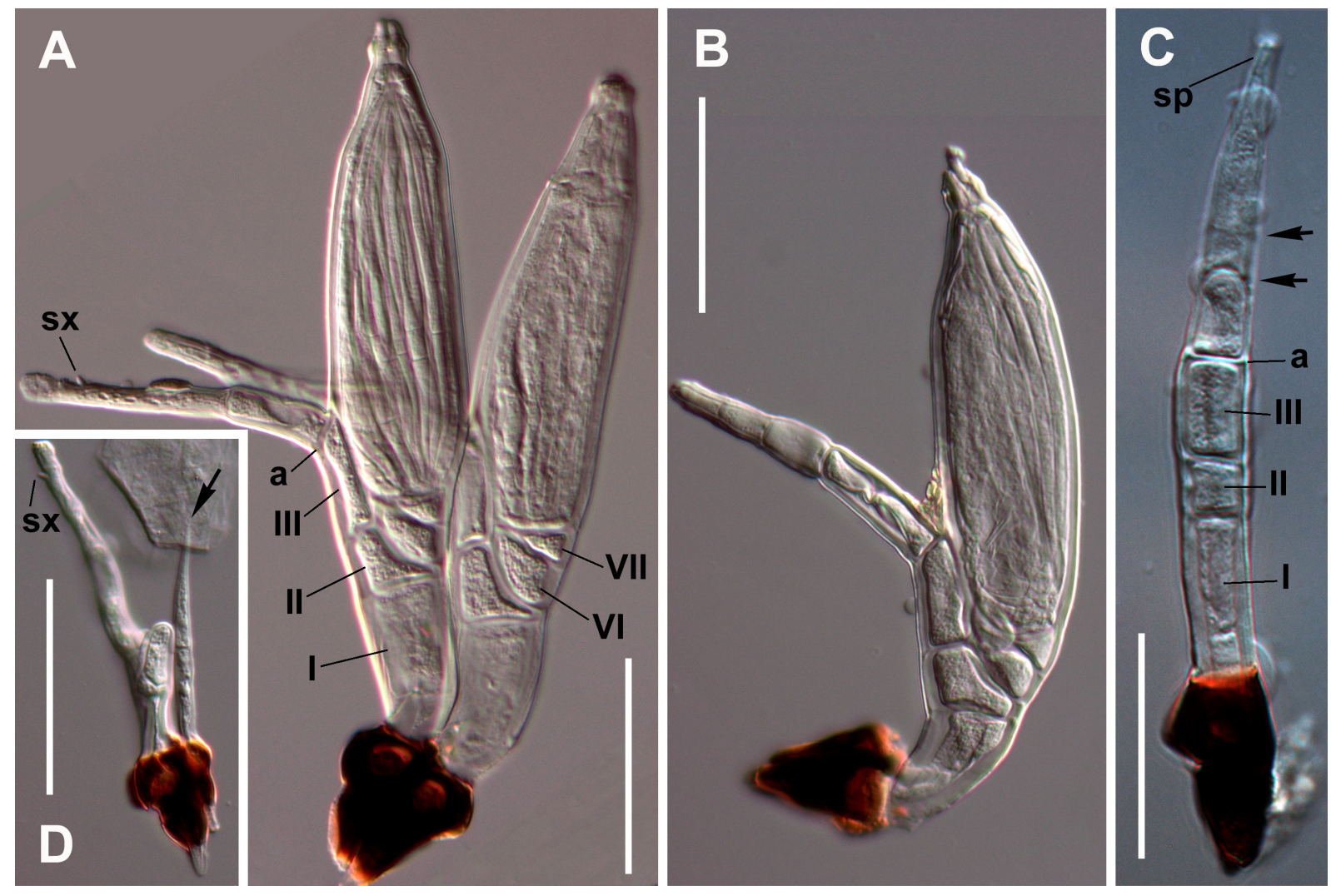

Fig. 4. Troglomyces dioicus Santam., Enghoff \& Reboleira sp. nov. A-B. Mature female thalli with labelling of cells and other elements. C. Mature male thallus with labelling of cells and other elements. D. Paired immature thalli where original spore apex are labelled (sx for female at left; arrow for male at right). Scale bars: $50 \mu \mathrm{m}$ (A-B, D), $25 \mu \mathrm{m}$ (C). Photographs from: SS E617a (A), SS E617c (B, D) and C-F-92269 (C). 
Length of male thalli from foot to apex of antheridium 88-93 $\mu \mathrm{m}$. Antheridium 21-26 $\times 5-6 \mu \mathrm{m}$. Length of female thalli from foot to apex of perithecium 159-201 $\mu \mathrm{m}$. Perithecium (including basal cells) 91-117 $\mu \mathrm{m}$. Primary appendage (from primary septum to apex, undamaged) $50-70 \mu \mathrm{m}$.

\section{Remarks}

This species is unique among the species of Troglomyces for its dioecism and because cell III, although adnate to perithecium (a characteristic of the genus) is located much lower than in other forms.

Male and female thalli are paired, as it is usual in dioecious Laboulbeniales. However as can be seen in Fig. 4A we have found a pair of females without any trace of antheridia or paired males (often seen as remains of the darkened feet, e.g., Fig. 4B).

The species seems very rare and the thalli were scarce on legs 2, 3 and several anterior post-gonopodal legs. Undamaged mature male thalli with spermatia present in the efferent neck have been seen only twice (Fig. 4C); immature thalli are more common and help us to understand that the efferent neck and pore (through which spermatia discharge) coincide with the original acute ascospore apex (Fig. 4D, arrow), an unusual feature among Laboulbeniales.

Dioecism is not unusual among genera of Laboulbeniales although most species are monoecious. A good example is the genus Laboulbenia Mont. \& C.P.Robin, with more than 600 species, only three were demonstrated to be dioecious (Santamaría 1998).

The host belongs to the large Southeast Asian genus Nepalmatoiulus Mauriès, 1983, which are mainly inhabitants of forest litter (Enghoff 1987).

Troglomyces tetralabiatus Santam., Enghoff \& Reboleira sp. nov. MycoBank No: MB824140

Fig. 5

\section{Diagnosis}

Similar but different from Troglomyces bilabiatus Santam. \& Enghoff (Enghoff \& Santamaría 2015) in having four protuberant perithecial apical lips instead of two.

\section{Etymology}

The species epithet is in relation to the four elongated lips on the perithecial apex.

\section{Material examined}

Holotype

GEORGIA: Abhkazia, Western Caucasus, Krubera-Voronya Cave (“deepest cave on Earth"), collected from 60 to 1980 meters below the surface, on Heterocancaseuma deprofundum Antić \& Reboleira, 2018 (Chordeumatida), 27 Jul.-9 Aug. 2010, S. Reboleira \& A. Sendra leg., slide C-F-92270.

\section{Isotypes}

GEORGIA: Same data as holotype. Slides SS E613a, SS E613b, SS E613c, SS E613d and SS E613f (BCB-Mycotheca).

\section{Paratypes}

RUSSIA: Peshchera Yuzhnyi Slon-“Southern Elephant”, Mt. Dzentu, Karachaevo-Cherkessia Republic, 1784 m a.s.1., on legs of the holotype of Caucaseuma elephantum Antić \& Makarov, 2016, no collecting 



Fig. 5. Troglomyces tetralabiatus Santam., Enghoff \& Reboleira sp. nov. A. Leg covered with thalli (see arrows for thalli, dark dots are blackened feet). B. Antheridium with spermatium. C. Mature thallus, with focus on scars near perithecial apex (arrows). D. Mature thallus with labelling of cells and other elements. E. Detail of perithecial apex showing the four conspicuous lips. F. Immature thallus with trichogyne (tr). G-H. Detail of well-developed primary appendages. I-K. Details of feet with digitations in side view (I-J) and in front view (K). Scale bars $100 \mu \mathrm{m}(\mathrm{A}), 50 \mu \mathrm{m}(\mathrm{F}), 25 \mu \mathrm{m}(\mathrm{C}-\mathrm{D})$, and $10 \mu \mathrm{m}$ (B, E, G-K). Photographs from: slides SS E614a (A), SS E615b (B), SS E584c (C), SS E613f (D), SS E613b (E), C-F-92270 (F) and SS E584b (G-K). 
date, Efremova leg., slides SS E615a and SS E615b (BCB-Mycotheca); Krasnodar Province, near Apsheronsk, Cave Sukhaya, on legs of the holotype of Caucaseuma minellii Antić \& Makarov, 2016, 21 Jul. 1970, S. Ljovuschkin leg., slide SS E616 (BCB-Mycotheca); Krasnodar Prov., Sochi, Abkhunskaya, Mt. Bolshoy, Akhun Cave, on Caucaseuma lohmanderi Strasser, 1970, 12 Jul. 2015, Turbasov leg., slides SS E614a and SS E614b (BCB-Mycotheca); Cave Shirokopokosskaya, near Khosta, on Caucaseuma lohmanderi, Dec. 1943, Y.A. Birstein leg., slide SS E618 (BCB-Mycotheca); Caucasus, Spirokoposkaja Cave, on Caucaseuma lohmanderi, Jul. 1943, J. Birstein leg., slide SS E584a and SS E584c (BCBMycotheca).

\section{Description}

Thallus hyaline, except for the blackened foot.

Basal cell (I) 1.5-3 times as long as broad, enlarged distally, strongly constricted at the base. Suprabasal cell (II) twice as broad as long, laterally adnate to cell VI, broadened at base where in contact with cell I, narrowed toward distal end. Cell III very narrow, up to 7 times as long as broad; laterally adnate to the perithecium, extending up to a third of the total length of the perithecium (lips included). Septum I-II horizontal. Septum II-III very short and oblique.

Primary appendage branched above the second and successive cells, rarely above first cell (Fig. 5D); short, not extending beyond the perithecial apex. Basal cell of primary appendage longer than other cells of appendage, about 2 times as long as broad. Primary septum constricted, strongly oblique. Antheridia flask-shaped, only clearly seen on immature thalli; usually a single one borne directly on second cell of appendage, sometimes supported by a short branch; sometimes a second and even a third antheridium may be found on the branches above. Antheridia deteriorate after maturation of thallus. Spiny remains of spore apex (sx) not seen.

Perithecial stalk cell (VI) inconspicuous, strongly flattened. Perithecium conical, the broadest part at the base, gradually tapering upwards. The apex bears 4 conspicuous identical, often distinctly divergent and curved lips, about 7 times as long as broad, arising through a scar.

Length from foot to apex of perithecium (including lips) $86-112 \mu \mathrm{m}$. Perithecium (including basal cells and lips) $60-73 \times 15-18 \mu \mathrm{m}$. Length of perithecial apical lips 10-18 $\mu \mathrm{m}$. Primary appendage (from primary septum to apex, undamaged) $21-33 \mu \mathrm{m}$.

\section{Remarks}

Among the hosts examined there are some with heavy infection on legs (Fig. 5A). Thalli found near the gonopods (slide SS E613f) are slightly different from others, therefore may be considered a growth form. Interesting are the digitations penetrating the tegument observed in some feet (Fig. 5I-K).

As mentioned in the diagnosis, this species is similar to Troglomyces bilabiatus, which lives on Acipes spp. (Blaniulidae) from Madeira and Canary Islands (Enghoff \& Santamaría 2015). Troglomyces tetralabiatus Santam., Enghoff \& Reboleira sp. nov. differs from Troglomyces bilabiatus by having four apical lobes instead of two, its more slender habitus and branched appendage. However, despite the morphological similarity it is hard to imagine a close relationship between two fungi living on such geographically and taxonomically isolated hosts.

The scar near the perithecial apex (Fig. 5C, arrows) was already described and discussed for five other species of Troglomyces (Enghoff \& Santamaría 2015). 
The hosts are cave-dwelling species of Western Caucasian anthroleucosomatid millipedes, belonging to genus Heterocaucaseuma and Caucaseuma. This species was found living in a cave at the remarkable depth of 1980 meters below the surface in the Krubera-Voronja Cave (Sendra \& Reboleira 2012; Antić et al. 2018). This makes it the "deepest" Laboulbeniales species on Earth. No significant difference regarding fungal position or thallus density was found when comparing hosts collected at different depths inside the cave.

\section{Additional records for previously known species}

Diplopodomyces lusitanipodos Santam., Enghoff \& Reboleira (Santamaría et al. 2014).

\section{Examined material}

SPAIN: Segovia Prov., Cancho del río Peces, Guadarrama, Mts. Mujer Muerta, 40 49'47.42"N 45'18.95"E, 1606 m a.s.1., on Guadarramasoma ramosae Gilgado, Ledesma, Enghoff \& Mauriès, 2017, MSS trap at 0.5 m, 17 Sep. 2015, J.D. Gilgado et al. leg., slides SS2760a and SS2760b (BCBMycotheca).

\section{Remarks}

The host is Guadarramasoma ramosae, a species collected in large numbers in traps set in the Mesovoid Shallow Substratum, MSS (Gilgado et al. 2017). This is the first record of Diplopodomyces lusitanipodos from a species of the order Chordeumatida; previously known hosts belong to the genera Lusitanipus and Cyphocallipus (Callipodida), reported from Portugal and Spain (Santamaría et al. 2014; Reboleira \& Enghoff 2015, 2017; Antić et al. 2018).

Troglomyces manfrediae S.Colla (Colla 1932)

\section{Examined material}

PORTUGAL: Madeira, Funchal, on Cylindroiulus truncorum Silvestri, 1896 (Julida), 1 Mar. 1992, Bjørn \& Damgaard leg., slide SS E622 (BCB-Mycotheca).

RUSSIA: Crimea, Ai-Petri Karst Region, Baydur Valley, near Rodnikovoe, Cave Skelskaya, on 2 females and 2 males of Amblyiulus kovalii Golovatch, 2008 (Julida), 3 Mar. 2015, I.S. Turbanov leg., slide SS E621 (BCB-Mycotheca).

SERBIA: Gornja Lenovacka Pedina Cave, Lenovac, near Zajecar, Tupiznica Mt., on Serboiulus kresnik Makarov, 2013 (Julida), 26 Jun. 2012, D. Antić \& S. Ćurčić leg., slide SS E586 (BCB-Mycotheca).

SPAIN: Granada, Sierra Nevada, Corral de La Veleta, on Proteroiulus hispanus Schubart, 1959 (Julida), 14 Aug. 2014, J.D. Gilgado et al. leg., slides SS2761a and SS2761b (BCB-Mycotheca).

\section{Remarks}

Previously known only from Typhloiulus Latzel, 1884 and Trogloiulus Manfredi, 1931 from Italy (Santamaría et al. 2014). The new records extend both the host range and the geographical distribution of this species. Among the new hosts, Cylindroiulus truncorum, Amblyiulus kovali and Serboiulus kresnik belong to the family Julidae, like previously known hosts, whereas Proteroiulus hispanus belongs to the related family Blaniulidae. Cylindroiulus truncorum is a widespread, largely synanthropic species with a preference for high humidity; Amblyiulus kovali and Serboiulus kresnik are cavernicolous (Haacker 1968; Kime \& Enghoff 2017). Infected specimens of Proteroiulus hispanus were collected at high altitude in Sierra Nevada, mainly in the Mesovoid Shallow Stratum, MSS (Gilgado et al. 2015). 


\section{Discussion}

The new species add significantly to the known geographical distribution of the genera Diplopodomyces and Troglomyces which were until now known only from Europe. Diplopodomyces is recorded from Sri Lanka and Turkey, Troglomyces from Myanmar and Georgia. With millipede-inhabiting species of the genus Rickia now known from Europe, Iran, tropical Africa, Sri Lanka, southeastern Asia, Australia and New Zealand (Santamaría et al. 2016) and the monotypic genus Triainomyces known from New Zealand (Rossi \& Weir 1998), millipede-inhabiting Laboulbeniales are now known from all biogeographical regions with the notable exceptions of the Nearctic and Neotropical (and Antarctic) ones.

Until Diplopodomyces and Troglomyces were monotypic, they appeared very distinct. Now that quite a few new species of these genera have been described, it is evident that they are very closely related. The discovery of new species has broadened the limits of the generic descriptions.

Tavares (1985), in the key of her monograph, separated Troglomyces because of cells II and III are narrow and adnate to the base and side of the perithecium. At the time of Tavares' work, the only known species in the genus was Troglomyces manfrediae S.Colla; moreover Tavares indicated that she never saw this taxon. Enghoff \& Santamaría (2015) emended the description of Troglomyces to broaden and refine some characteristics relating to antheridial structures. The inclusion here of a new dioecious species (Troglomyces dioicus Santam., Enghoff \& Reboleira sp. nov.) further modifies the generic limits.

Diplopodomyces was compared with Autophagomyces Thaxter (Rossi \& Balazuc 1977), and a common ancestor was even suggested (Tavares 1985). In the key published by Tavares (1985) it is mentioned that Diplopodomyces shows very small and not readily visible basal cells and secondary stalk cell of perithecium. This characteristic is not present at least in Diplopodomyces coronatus sp. nov. (Fig. 1A) or Diplopodomyces ramosus sp. nov. (Fig. 3A). Also, a feature that is broadly accepted as very important to separate genera is the number of perithecial wall cells which, however, for each vertical row varies from the five mentioned in Tavares' key to the four seen in, for example, in Diplopodomyces coronatus sp. nov. In steps 59 and 59' of the key, Diplopodomyces and Troglomyces are separated by the limited growth of the appendage in Diplopodomyces in contrast to its indefinite growth, with branching, in Troglomyces. With our present knowledge this distinction is questionable because only Diplopodomyces callipodos meets this criterion.

Two main types of distribution of thalli on the host body can be discerned among Laboulbeniales growing on millipedes. Some species are exclusively, or at least predominantly, found on parts of the host's body which come in contact during mating. Others are more widely distributed on the body and probably are transferred via the substrate or via non-sexual contacts (Enghoff \& Santamaría 2015). Among the new species described here, Diplopodomyces ramosus sp. nov., Troglomyces dioicus sp. nov., and possibly Diplopodomyces liguliphorus Santam., Enghoff \& Reboleira sp. nov. and Troglomyces tetralabiatus sp. nov. seem to belong to the first category, Diplopodomyces coronatus sp. nov. to the second. The scattered distribution of Diplopodomyces lusitanipodos on the body of its new host is in line with the one observed on previously recorded hosts (Santamaría et al. 2014).

\section{Acknowledgments}

We kindly acknowledge Nesrine Akkari for access to the NHMW collection; and Dragan Antić, Adam Brunke, Jose Gilgado, Sergei Golovatch, Pavel Stoev, Henrik Sundberg and the Cavex Team for providing millipede specimens with Laboulbeniales. This project was funded by the Danish Council for Independent Research (DFF-FNU 4002-00269) and by a research grant (15471) from VILLUM FONDEN. 


\section{References}

Antić D., Turbanov I.S. \& Reboleira A.S.P.S. 2018. From the depths - Heterocaucaseuma deprofundum sp. nov. - the world's deepest millipede (Diplopoda, Chordeumatida, Anthroleucosomatidae). Zootaxa 4377 (1): 110-124.

Báthori F., Rádai Z. \& Tartally A. 2017. The effect of Rickia wasmannii (Ascomycota, Laboulbeniales) on the aggression and boldness of Myrmica scabrinodis (Hymenoptera, Formicidae). Journal of Hymenoptera Research 58: 41. https://doi.org/10.3897/jhr.58.13253

Benjamin R.K. 1971. Introduction and supplement to Roland Thaxter's contribution towards a monograph of the Laboulbeniaceae. Bibliotheca Mycologica 30: 1-155.

Colla S. 1932. "Troglomyces Manfredii" n.gen. et n.sp.: nuova Laboulbeniacea sopra un miriapode. Nuovo Giornale Botanico Italiano 39: 450-453.

Csata E., Bernadou A., Rákosy-Tican E., Heinze J. \& Markó B. 2017. The effects of fungal infection and physiological condition on the locomotory behaviour of the ant Myrmica scabrinodis. Journal of Insect Physiology 98: 167-172. https://doi.org/10.1016/j.jinsphys.2017.01.004

Enghoff H. 1987. Revision of Nepalmatoiulus Mauries 1983 - a southeast Asiatic genus of millipedes (Diplopoda: Julida: Julidae). Courier Forschungs-Institut Senckenberg 93: 241-331.

Enghoff H. \& Santamaría S. 2015. Infectious intimacy and contaminated caves - three new species of ectoparasitic fungi (Ascomycota: Laboulbeniales) from blaniulid millipedes (Diplopoda: Julida) and inferences about their transmittal mechanisms. Organisms Diversity \& Evolution 15 (2): 249-263. https://doi.org/10.1007/s13127-015-0208-8

Frederiksen S.B., Petersen G. \& Enghoff H. 2012. How many species are there of Pachyiulus? A contribution to the taxonomy of Europe's largest millipedes (Diplopoda, Julida, Julidae). Journal of Natural History 46: 599-611. https://doi.org/10.1080/00222933.2011.651636

Gilgado J.D., Enghoff H., Tinaut A., Mauriès J.P. \& Ortuño V.M. 2015. Sierra Nevada (Granada, Spain): a high-altitude biogeographical crossroads for millipedes (Diplopoda), with data on its MSS fauna and description of a new species of the genus Ceratosphys Ribaut, 1920 (Chordeumatida: Opisthocheiridae). Zootaxa 4044 (3): 391-410. https://doi.org/10.11646/zootaxa.4044.3.4

Gilgado J.D., Ledesma H., Enghoff H., Mauriès J.P. \& Ortuño V.M. 2017. A new genus and species of Haplobainosomatidae (Diplopoda: Chordeumatida) from the MSS of the Sierra de Guadarrama National Park, central Spain. Zootaxa 4347 (3): 492-510. https://doi.org/10.11646/zootaxa.4347.3.4

Haacker U. 1968. Deskriptive, experimentelle und vergleichende Untersuchungen zur Autökologie rhein-mainischer Diplopoden. Oecologia 1: 87-129. https://doi.org/10.1007/BF00377255

Jolivet P. 1998. Interrelationship between insects and plants. CRC press, Florida, USA.

Kime R.D. \& Enghoff H. 2017. Atlas of European millipedes 2: Order Julida (Class Diplopoda). European Journal of Taxonomy 346: 1-299. https://doi.org/10.5852/ejt.2017.346

Konrad M., Grasse A. V., Tragust S. \& Cremer S. 2014. Anti-pathogen protection versus survival costs mediated by an ectosymbiont in an ant host. Proceedings of the Royal Society B 282: 20141976. https://doi.org/10.1098/rspb.2014.1976

Lawrence J.F. \& Milner R.J. 1996. Associations between arthropods and fungi. Fungi of Australia 1: $137-202$. 
Reboleira A.S.P.S. \& Enghoff H. 2015. Redescription of Lusitanipus alternans (Verhoeff, 1893) (Diplopoda, Callipoda, Dorypetalidae) and ecological data on its Laboulbeniales ectoparasites in caves. Zootaxa 3957 (5): 567-576. https://doi.org/10.11646/zootaxa.3957.5.5

Reboleira A.S.P.S. \& Enghoff H. 2017. Subterranean millipedes (Diplopoda) of the Iberian Peninsula. Zootaxa 4317 (2): 355-369. https://doi.org/10.11646/zootaxa.4317.2.10

Rossi W. \& Balazuc J. 1977. Laboulbeniales parasites de Myriapodes. Revue de Mycologie (Paris) 41: $525-535$.

Rossi W. \& Santamaría S. 2015. New species of Aporomyces. Turkish Journal of Botany 39 (2): 354 358. https://doi.org/10.3906/bot-1404-104

Rossi W. \& WeirA. 1998. Triainomyces, a new genus of Laboulbeniales on the pill-millipede Procyliosoma tuberculatum from New Zealand. Mycologia 90 (2): 282-289. https://doi.org/10.2307/3761304

Santamaría S. 1998. Laboulbeniales, I. Laboulbenia. Flora Mycologica Iberica 4: 1-186.

Santamaría S., Enghoff H. \& Reboleira A.S.P.S. 2014. Laboulbeniales on millipedes: the genera Diplopodomyces and Troglomyces. Mycologia 106 (5): 1027-1038. https://doi.org/10.3852/13-381

Santamaría S., Enghoff H. \& Reboleira A.S.P.S. 2016. Hidden biodiversity revealed by collectionsbased research - Laboulbeniales in millipedes: genus Rickia. Phytotaxa 243 (2): 101-127. https://doi.org/10.11646/phytotaxa.243.2.1

Santamaría S., Enghoff H., Gruber J. \& Reboleira A.S.P.S. 2017. First Laboulbeniales from harvestmen: the new genus Opilionomyces. Phytotaxa 305 (4): 285-292. https://doi.org/10.11646/phytotaxa.305.4.4

Scheloske H.W. 1969. Beiträge zur Biologie, Ökologie und Systematik der Laboulbeniales (Ascomycetes) unter besonderer Berücksichtigung des Parasit-Wirt-Verhältnisses. Parasitologische Schriftenreihe 19: $1-176$

Sendra A. \& Reboleira A.S.P.S. 2012. The world's deepest subterranean community - KruberaVoronja Cave (Western Caucasus). International Journal of Speleology 41 (2): 221-230. https://doi.org/10.5038/1827-806X.41.2.9

Strandberg J.O. \& Tucker L.C. 1974. Filariomyces forficulae: occurrence and effects on the predatory earwig, Labidura riparia. Journal of Invertebrate Pathology 24: 357-364. https://doi.org/10.1016/0022-2011(74)90144-X

Tamada Y. \& Kaya H. 1993. Insect pathology. Academic Press INC, New York.

Tavares I.I. 1985. Laboulbeniales (Fungi, Ascomycetes). Mycological Memoirs 9: 1-627.

Thaxter R. 1896. Contribution towards a monograph of the Laboulbeniaceae. Memoirs of the American Academy of Arts and Sciences 12: 187-429.

Tragust S., Tartally A., Espadaler X. \& Billen J. 2016. Histopathology of Laboulbeniales (Ascomycota: Laboulbeniales): Ectoparasitic Fungi on Ants (Hymenoptera: Formicidae). Myrmecological News 23: $81-89$.

Weir A. \& Hammond P.M. 1997. Laboulbeniales on beetles: host utilization patterns and species richness of the parasites. Biodiversity \& Conservation 6 (5): 701-719. https://doi.org/10.1023/A:1018318320019

Whisler H.C. 1968. Experimental studies with a new species of Stigmatomyces (Laboulbeniales). Mycologia 60: 65-75. https://doi.org/10.2307/3757314 
Manuscript received: 15 December 2017

Manuscript accepted: 22 February 2018

Published on: 27 April 2018

Topic editor: Frederik Leliaert, PhD and Koen Martens

Desk editor: Alejandro Quintanar

Printed versions of all papers are also deposited in the libraries of the institutes that are members of the EJT consortium: Muséum national d'Histoire naturelle, Paris, France; Botanic Garden Meise, Belgium; Royal Museum for Central Africa, Tervuren, Belgium; Natural History Museum, London, United Kingdom; Royal Belgian Institute of Natural Sciences, Brussels, Belgium; Natural History Museum of Denmark, Copenhagen, Denmark; Naturalis Biodiversity Center, Leiden, the Netherlands; Museo Nacional de Ciencias Naturales-CSIC, Madrid, Spain; Real Jardín Botánico de Madrid CSIC, Madrid, Spain. 